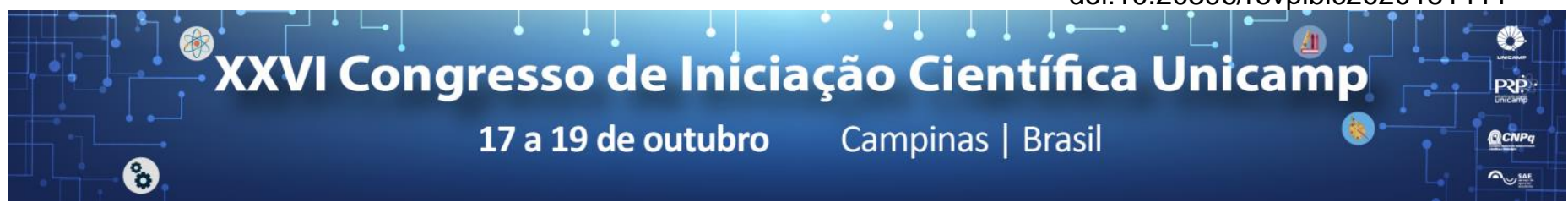

\title{
Conhecimentos e atitudes em saúde bucal dos professores e alunos de escolas do nível médio
}

\author{
Bruna C. Sanches, Mirian P. Silva, Rebeca Freires, Wilson G. Cral, Dagmar P. Queluz
}

\begin{abstract}
Resumo
O objetivo deste trabalho foi avaliar os conhecimentos e atitudes em saúde bucal dos professores e alunos de escolas do nível médio na cidade de Piracicaba. A amostra selecionada foi de professores e alunos de escola pública do ensino médio que responderam a um questionário estruturado sobre: promoção e prevenção em saúde bucal, autopercepção em saúde bucal, satisfação com a condição da saúde geral e bucal, hábitos de higiene bucal, conhecimento em saúde bucal; além de aspectos sócios demográficos. Os questionários foram respondidos por 151 ALUNOS com idade média de 15,77 anos. A maioria deles: $69,53 \%$ costuma olhar a boca e os dentes com frequência, $98,67 \%$ não possue ferida na boca, $95,36 \%$ não possue mau hálito e $91,39 \%$ alega não ter problemas na gengiva, $59,60 \%$ considera a saúde bucal satisfatória, 35,09\% procura tratamento odontológico para realização de limpeza. 16 PROFESSORES com idade média de 40 anos, responderam que a maioria deles: costuma olhar a boca e os dentes diariamente, não tem ferida na boca, não tem mau hálito, não apresenta sangramento na gengiva sem motivo ou quando passa fio dental ou quando escova o dente, não tem dor nos dentes ou na boca, considera a saúde geral satisfatória, considera a saúde bucal satisfatória, tem hábitos e conhecimentos regulares de higiene bucal. Em vista da maioria dos alunos e professores demonstrarem bons resultados, permiti concluir que a atenção com a saúde bucal, e em especial a educação em saúde, são necessárias nas escolas, sendo a prevenção a melhor forma de diminuir doenças.
\end{abstract}

\section{Palavras-chave:}

Saúde Escolar, Educação em Odontologia, Saúde Bucal.

\section{Introdução}

As ações de promoção da saúde devem ser realizadas por meio da educação, engajamento em novos estilos de vida e desenvolvimento intelectual do indivíduo. Para tornar as práticas educativas e preventivas em saúde parte do cotidiano didáticopedagógico dentro das instituições de ensino, é necessário a cooperação entre os setores da educação e da saúde. A educação em saúde bucal é importante por permitir ao indivíduo conhecimento sobre as doenças bucais que podem acometê-lo, bem como sobre a melhor forma para sua prevenção.

O objetivo deste trabalho foi avaliar os conhecimentos e atitudes em saúde bucal dos professores e alunos de escolas do nível médio na cidade de Piracicaba.

\section{Resultados e Discussão}

O estudo foi aprovado pelo Comitê de Ética em Pesquisa da Faculdade de Odontologia de Piracicaba UNICAMP, pelo protocolo no 84/2015. A amostra selecionada foi de professores e alunos de escola pública do ensino médio de Piracicaba, participante do Programa Institucional de Bolsa de Iniciação Científica para o Ensino Médio - PIBIC EM. Os critérios de inclusão foram: idade maior ou igual a 15 anos se estiver acompanhado/autorizado pelo responsável, participação voluntária esclarecida e preenchimento do questionário estruturado.

151 alunos e 16 professores responderam a um questionário estruturado sobre: promoção e prevenção em saúde bucal, autopercepção em saúde bucal, satisfação com a condição da saúde geral e bucal, hábitos de higiene bucal, conhecimento em saúde bucal; além de aspectos sócios demográficos.
151 ALUNOS com idade média de 15,77 anos \pm 0,96 , entre 15 a 18 anos, sendo 79 do sexo feminino $(52,31 \%)$ e 72 do sexo masculino $(47,68 \%)$. sendo 61 $(40,39 \%)$ do $1^{\circ}$ ano, $63(41,72 \%)$ do $2^{\circ}$ ano, e 26 $(17,21 \%)$ do $3^{\circ}$ ano. A maioria $(105,69,53 \%)$ costuma olhar a boca e os dentes com frequência, 149 (98,67\%) não possuem ferida na boca, 144 (95,36\%) não possuem mau hálito e 138 alunos (91,39\%) alegam não ter problemas na gengiva. Em relação a saúde bucal, 90 $(59,60 \%)$ consideram satisfatória e $58(38,41 \%)$ relatam que precisam melhorar. A maioria $(53,35,09 \%)$ procura tratamento odontológico para realização de limpeza, seguido de tratamento ortodôntico $(21,13,90 \%)$, tratamento de cárie $(17,11,25 \%)$ e dor $(12,7,94 \%)$.

16 PROFESSORES com idade média de 40 anos entre 28 e 50 anos; 13 mulheres (81,25\%) e 3 homens (18,75\%). A maioria deles: costuma olhar a boca e os dentes diariamente, não tem ferida na boca, não tem mau hálito, não apresenta sangramento na gengiva sem motivo ou quando passa fio dental ou quando escova o dente, não tem dor nos dentes ou na boca, considera a saúde geral satisfatória, considera a saúde bucal satisfatória, tem hábitos e conhecimentos regulares de higiene bucal.

\section{Conclusões}

Em vista da maioria dos alunos e professores demonstrarem bons resultados, permiti concluir que a atenção com a saúde bucal, e em especial a educação em saúde, são necessárias nas escolas, sendo a prevenção a melhor forma de diminuir doenças.

\section{Agradecimentos}

